\title{
Organizational justice and cynicism: a mixed method study at schools
}

\author{
Hüseyin Akar ${ }^{1}$, O. Tayyar Çelik ${ }^{2}$ \\ ${ }^{1}$ Department of Educational Sciences, Kilis 7 Aralik University, Kilis, Turkey \\ ${ }^{2}$ Department of Student Affairs, Pamukkale University, Denizli, Turkey
}

\begin{tabular}{l} 
Article Info \\
\hline Article history: \\
Received Feb 10, 2019 \\
Revised Feb 28, 2019 \\
Accepted March 22, 2019 \\
\hline
\end{tabular}

Keywords:

Organizational justice Organizational cynicism School

Teacher

\begin{abstract}
This study aimed to investigate the relationship between organizational justice and cynicism at school organizations. Thus, explanatory sequential research design, in which both qualitative and quantitative methods are used, has been used. Under the quantitative part, meta-analysis has been used so that 159 studies consist of articles and dissertations about cynicism being done within Turkey have been reached throughout literature. With further enquiries, it was found that 16 of them include the relationship between organizational justice and cynicism. Considering inclusion criteria, eight studies which include necessary data for the relationship between organizational justice and cynicism were put into meta-analysis step. However, in the qualitative part, the research was designed through phenomenological research design in which 17 teachers, chosen in terms of maximum-variation sampling strategy, were interviewed via a semistructured interviewing form. The results revealed that teachers' perceptions for organization justice have a strong but negative effect on their likelihood to experience cynicism while it was also found that publication type is not a proper moderator on effect size. On the other hand, within the qualitative analysis, it was found that teachers develop negative beliefs against school, managers and teachers; experience feelings such as anger, distrust, sadness, hatred and alienation and thus criticize school and managers, behave recklessly and opponent as a result of unfair practices.
\end{abstract}

Copyright (C) 2019 Institute of Advanced Engineering and Science. All rights reserved.

\section{Corresponding Author:}

Hüseyin Akar

Department of Educational Sciences,

Kilis 7 Aralik University,

Mehmet Sanli District, Doğan Güreş Paşa Avenue, No:134, Kilis, Turkey

Email: huseyinakar@kilis.edu.tr

\section{INTRODUCTION}

Many important things have changed within the managing approaches for maintaining organizational effectiveness from past to present. One of the vital bases in these changes is the perspective for human-beings. Members of an organization, who were once accepted as agents to mechanically fulfil any duties given without paying attention to their emotions, are now taken as important factors driving organizational effectiveness with their emotions and behaviours. Like in others, members' emotions, beliefs, interests, values, character types and attitudes play an important role in realizing organizational objectives within schools of which both input and output are human at the same time. Thus, it has gained much more important to investigate variables affecting members' beliefs, emotions and behaviours in school organizations where human relations are primary.

Justice or justice-related problems, as important variables affecting employees' behaviours, are key figures for almost all employees. The term, justice, has always been a phenomenon with its effect on individual both in daily life and organization as well. Although the term, justice, has been studied in different 
disciplines such as philosophy, sociology and law from Aristo to present day, the total interest on it has risen since it was studied in organizational context. Justice is a complex and multi-sided phenomenon in terms of why people care for it, how they evaluate its different sides and their styles of using justice to shape individual attitudes and behaviours [1]. Justice, in its most common meaning, can be defined as to give anyone what they deserve. Whereas, organizational justice is related to employees attitudes on whether they are behaved properly and fair by the organization [2]. People generally bring their knowledge and experiences into organizations and transform their capabilities into an investment for both themselves and the organization's sake as well. So that it is totally normal for people to be in expectation for fair payment, promotion and reputation with regard to their rate of contribution to the organization [3]. So whether these expectations are met or not in proportion to their contribution is the basis of organizational justice.

Organizational justice is the employees' perceptions for how material, immaterial and social sources of the organization are distributed, the quality of communication and interaction with managers. Employees frequently evaluate if the rewards they received are consistent with their contribution to the organization and even with the ones their colleagues received. According to Sabuncuoğlu \& Tüz [4], organizational justice is an individual evaluation of the ethical state of managerial behaviours. When we consider organizational justice in its historical process, it emphasizes payment and results and comparisons of these with the others'. The possible disappointment and satisfaction, being revealed as a result of relative deprivation at end of evaluation based on comparisons, have been analysed [5]. Specifically, organizational justice is regarded as having three major dimensions as distributive justice, procedural justice and interactional justice in the literature [6- 8].

Distributive justice is defined as the perceived fairness of allocating sources by employees according to their performances and input [9]. Distributive justice is, thus, based on Adams' theory of equity. The theory is also based on the assumption that employees expect high payments with regard to their high performances. This evaluation includes the comparison of the knowledge and skills that individuals have with those of other employees have and obtain [8]. Distributive justice directly deals with the final results while procedural justice deals with the ways to reach final results [10, 11]. Finally, Bies \& Moag [12] added a new dimension to organizational justice by drawing our attention to interactional justice while applying procedures. Interactional justice depends on interpersonal interactions while emphasizing whether they are well behaved in accordance with employee reputation, kindness and prestige.

The organizational justice perception and the employees' emotional and behavioural reactions based on this perception have been explained by means of social exchange theory [13]. According to social exchange theory, when employees experience highly fair practices within the organization, they act to continue these practices and develop their organizations. These employees' possibility to react against their organization, harm or to stop organizational practices is much lower [14]. Whereas, the employees' possibility, whose organizational justice perception is relatively lower, to maintain a negative attitude is higher. However, the studies on teachers have revealed that organizational justice perception predicts organizational silence and cynicism [15], quitting job [16] negatively; whereas positively predicting organizational commitment [17], job motivation [18, 19], additional roles for students [20] and dedicating into job [21].

The reason why organizational justice has been mostly studied in various organizations is its effect on employees' attitudes and behaviours [22]. It is likely for those teachers who have experienced unfairness at school to develop negative emotions, thoughts and behaviours. These negative emotions, thoughts and behaviours are described as cynicism in the literature [23]. Cynicism, an antique Greek philosophy, etymologically dates back to 500 B.C. which points out living simple and virtuous while criticizing social rules via humour [24]. This way of life was first modelled through searching an honest man in the day time but with a lamp by Diogenes, one of the students of Antisthenes, who is also accepted as the first cynics. Social problems of the era lie behind the cynicism philosophy. It is known that political and cultural corruption in Greek and Athens states led to unhappiness and despair [25]. The term also has some negative connotations at modern ages. A cynic is a person who refuses ethical values and ideas, examines even honesty and faithfulness, doubts the most innocents and favourable also and finally reacts [26, 27].

Although the ancient philosophers took cynicism as a lifestyle [28], nowadays it has become a phenomenon being studied in sociology, psychology, health and organizational behaviours. In literature, the term cynicism is sometimes used the same as scepticism [29] and misanthropy as well. However, these are different terms. According to Kutanis \& Dikili [30], while cynicism is a stable character type, scepticism can be disappeared by means of valid pieces of evidence. Misanthropy, on the other hand, refers to the denial of official culture by sub-groups of society while cynicism represents a reaction against this social decomposition [27].

Cynicism is characterized through negative attitudes against organization, hopelessness, disappointment and distrust [31]. The employees with cynics' ideas within the organization believe that there

Int. J. Eval. \& Res. Educ. Vol. 8, No. 1, March 2019:189- 200 
are secret objectives for organizational actions and thus there is no probability for official reasons, developed by managing bodies, to be accepted. As a result cynic individuals believe that organizational actions do not include justice, honesty and sincerity [28]. To Demir [27], employees do not perform cynic behaviours intentionally. This attitude, instead, emerges as a result of experiences. So it can be stated that any individual is not born as a cynics but, rather, he becomes in time according to his experiences. Scholars accept cynicism as a learned behaviour based on injustice and disappointment within the organization. The disappointment that the employee carries will lead to negative perspectives and poor expectations [32]. The cause and effect relationship is bilateral in member-organization exchange. This flow is both from organization to the member, and from member to organization [33]. Insincere relations and unfair practices within the organization become cynic attitudes and behaviours in time. Naus, Van Iterson \& Roe [34] stated that organizational cynicism consists of employees' perceptions about unfair and fake practices, fictional behaviours, insincerity and deception.

Within the studies dealing with the results of organizational cynicism, it is stated that cynicism has many negative effects. Moreover it has been found that cynicism has negative correlation with positive organizational behaviour variables such as job satisfaction [35, 25], organizational commitment [36], organizational citizenship behaviours [37]; while positive correlation with negative organizational behaviour variables such as burnout [38] and job alienation [39]. Though, Brandes \& Das [28] claimed that cynicism would have some positive effects. To them, cynicism may prevent burnout and job-related stress as a coping mechanism by means of increasing employees' critical thinking capacity and helping them to talk about their problems. Nevertheless, it can be concluded that there are more studies on cynicism about its negative sides rather than positive ones in literature.

Organizations must consider cynicism seriously, try to understand and take various precautions [4]. So that it has become much more important to investigate variables affecting cynicism. In many studies dealing with schools [40-47], organizational justice has been taken as an antecedent of cynicism. However, it cannot be concluded that there is an agreement by considering current studies. Then, we cannot find any study investigating the relationship between organizational justice and cynicism not only via meta-analytical methods but also qualitative as well. So that our main motivation for this study is to synthesise the relationship between organizational justice perception and organizational cynicism according to current literature and to reveal what sort of cynicism occurs as a result of these unfair practices according to teachers' views.

\section{RESEARCH METHOD}

Mixed-method strategy, using qualitative and quantitative together, was preferred in this study. There are different designs reflecting interaction, priority, timing and combining in mixed-methodology. Therefore, by considering priority and timing, explanatory sequential design was used in this study. Throughout explanatory sequential design consists of two interactional steps. First, quantitative data is collected and analysed and then qualitative is analysed to explain quantitative findings and reinterpret [48]. The design is shown in Figure 1.

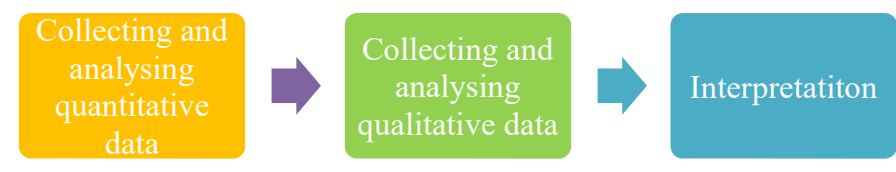

Figure 1. The study design

In collecting and analysing quantitative data, the literature we scanned and these, suitable for metaanalysis were taken and analysed among studies dealing with the relationship between organizational justice and cynicism. Meta-analysis enables us to combine and reinterpret studies, done in different samples, time and place, on a specific subject/topic.

Phenomenology was used in the next step of the study. Within phenomenology, we focus on the phenomenon which we are aware of but not know much [49]. In this approach, a phenomenon is described according to individuals' and groups' experiences [50]. So, what sort of beliefs are developed, which emotions emerge and how individuals react against any unfair practice at schools are tried to be revealed. Therefore, the qualitative data, collected via a semi-structured interviewing form, has been analysed by means of a qualitative approach. At the final stage, both qualitative and quantitative data were analysed and reinterpreted.

Organizational justice and cynicism: a mixed method study at schools (Hüseyin Akar) 


\subsection{The studies put into meta-analysis and study group of qualitative step}

\section{a. The studies put into meta-analysis}

In order to determine the studies to be taken for meta-analysis, first, databases such as Google Scholar, Ulakbim-Social and Human Sciences, YOK Dissertations, ERIC and Web of Science were all scanned by means of keywords such as "cynicism", "organizational cynicism", "cynicism at school organizations". Scanning process was completed on the 2nd of November 2018. 159 studies (articles and dissertations) related to cynicism being held in Turkey within schools were reached. Then, it was concluded that in 16 of these studies the relationship between organizational justice and cynicism was investigated. In order to decide whether to put these studies into meta-analysis step, pre-determined criteria were used. These criteria are as such: being realized between 2000 and 2018; to be either a research article or dissertation; to cover teachers from state or private schools as a sample; being accessible; to prefer dissertation form if it was suitable in both dissertation and research article; to include statistical values such as the number of sample $(\mathrm{n})$, correlation $(r)$ or regression $\left(r^{2}\right)$ coefficients which are essential for meta-analysis.

Considering these 16 studies together with these including criteria, it was determined that 8 of them were suitable for meta-analysis process. Descriptive statistics are given for these eight studies in Table 1.

Table 1. Descriptive statistics for the studies put in meta-analysis

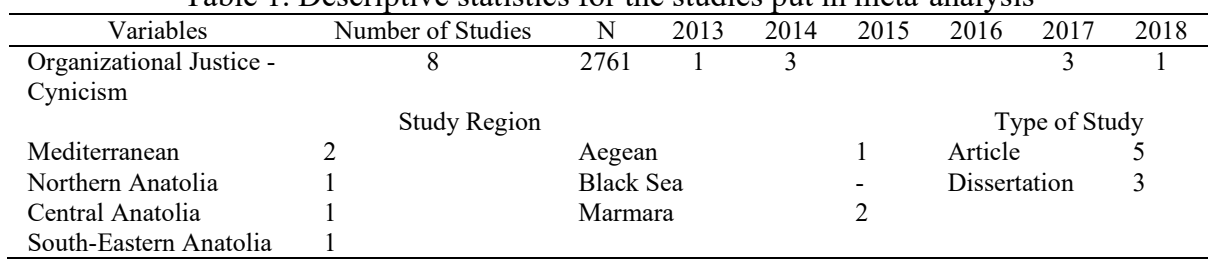

As it is seen in Table 1, the studies chosen for meta-analysis was done in and after 2013, 5 is research article while the remaining 3 is dissertation. When we consider where these studies were held, at least one study is included from each region except for the Black Sea. Finally, the total sample number for these 8 studies is up to 2761 .

\section{b. Study group for qualitative step}

The study group for the qualitative step was chosen by means of the maximum-variation sampling technique. With this, the main purpose is to create a smaller sample and maximize the individual types who can be related to the subject [49]. Then, it was tried to be realized by putting male and female teachers together, while on the side different school types and levels were also represented. According to Baş \& Akturan [51], the main point for this of studies is to decrease the number of study group but increase the quality of the data gathered. The study group is identified in Table 2.

Table 2. Study group for qualitative step

\begin{tabular}{lcccc}
\hline Gender & Total & Female & Male & \\
\hline $\mathrm{N}$ & 17 & 8 & 9 & \\
School Type & & Primary & Secondary & High school \\
$\mathrm{N}$ & 17 & 4 & 6 & 7 \\
\hline
\end{tabular}

\subsection{Data analysis}

a. Recoding the data for meta-analysis and analysing process

The research studies being put in the meta-analysis were classified according to certain categories (author, year, sample, scope, place, correlation coefficients) by means of Microsoft Office Excel. So that a very coding form was created dealing with study core information. Then, these data were entered in CMA 2.0 (Comprehensive Meta-Analysis 2.0) and analysed. In the meta-analysis, methodology data is analysed with regard to two different models. These are the fixed effects model (FEM) and the random effects model (REM). It depends on the study's objective of whether to FEM or REM. Random effects model was used in this research because the studies, being put in the meta-analysis, were supposed not to be functionally equal. Moreover, it is aimed to generalize the effect sizes, being expected to be obtained with analysis, into larger samples [52]. In this study, a correlational meta-analysis was used to calculate effect sizes in which pure correlational coefficients (r) and sample size (n) are adequate. To reinterpret these core values, the classification index suggested by Cohen, Manion \& Morrison [53] was used [“.00-.10" too weak, ".10-.30" weak, ". $30-.50 "$ medium, ".50-.80" strong, ".80 $\leq$ " too strong].

Int. J. Eval. \& Res. Educ. Vol. 8, No. 1, March 2019:189- 200 


\section{b. Collecting qualitative data and analysis}

In collecting qualitative data, a semi-structured interviewing form, developed by us, was used. An example of injustice behaviours was given through a short reading passage within the interviewing form, and the participants were asked whether they had faced to similar things at their own schools and it was tried to be determined that what type of reactions or emotions occurs in such practices. So the interviewing form consists of hypothetical and open-ended questions. Hypothetical questions are speculative ones through which it is possible to learn about how a person would behave against a special case [54].

The participants were all informed about the research objectives and possible interviewing duration. They were also asked to give permission for voice-recording in which five agreed while the rest were interviewed via note-taking. After each interview, the participant was asked to check the taken notes, approximately the interviews lasted for 35 minutes.

Both descriptive and content analysis techniques were used in analysing qualitative data. The data is analysed in terms of pre-defined themes and summarized with regard to descriptive analysing technique. Not only it is possible to organize data according to the themes that the interview questions have revealed but also you can present them by considering the questions or even process [49]. Three themes were defined in accordance with the interviewing questions by the researchers. These are the reflection of unfair practices upon cognitive, emotional and behavioural dimensions of cynicism. Similar codes and data are given with frequencies under pre-defined themes by means of content analysis. According to Merriam [54], all qualitative analyses are content-based as the contents of interviews, field notes and documents are in fact analysed.

Before beginning to data analysis, the voice recordings and notes were all transferred to computerassisted word processor programme. Each participant was coded as K1, K2, K3. Thanks to pre-defined themes, the coding process directly started. The coding system is divided into three as open coding, axial coding and elective coding [55]. Under the open coding step, an overall reading was done and keywords and statements were tried to be put under proper themes. During the axial coding process, the data was deeply read again and newly found keys were put under the themes they were related to. Finally, at elective coding step, a final reading was done to put any possible new keys under themes. Themes with codes were organized under tables and while interpreting them direct quotations of participants were also used.

One of the top challenging items for qualitative researches is reliability and validity [56, 57] According to Creswell [56], reliability in qualitative studies relies under the consistency between different coders on data set. Thus the data set, participants' views, were coded by both researchers separately. Then the results were reconsidered according to the formula suggested by Miles \& Huberman [58] and final reliabilityindex was calculated as \% 86. Both researchers' codes were compared and evaluated together to stabilize codes and themes. Three types of validity can be stated in qualitative studies which are descriptive, interpretive and theoretical validities [50]. With regard to descriptive validity, the data were analysed by the researchers separately and then an external fellow was asked to examine these codes and themes. So that researcher diversification was guaranteed. In order to provide interpretive validity, codes and themes were put together under certain tables together with direct quotations. Also, a final overall examination was run to be sure that codes and themes were suitable for existing theories.

\section{FINDINGS}

\subsection{Findings for quantitative step}

Within the quantitative step of the research; first, the problem of publication bias was investigated for the studies put in the meta-analysis. Publication bias is a situation in which all the publications about a specific subject area are not taken in the analysis process. It is because some researchers have a tendency towards taking the studies which include significant differences or relations. This leads to publication bias in meta-analysis studies and deviations in effect sizes calculated [52, 59]. Thus, it must definitely be investigated whether there is publication bias or not with regard to the studies being put in the meta-analysis. There are different techniques to investigate publication bias. Funnel Plot, Egger Test, Classic Fail Safe N and Duval \& Tweedie's Trim and Fill were used through this study. The Funnel Plot for the studies taken is given in Figure 2. 


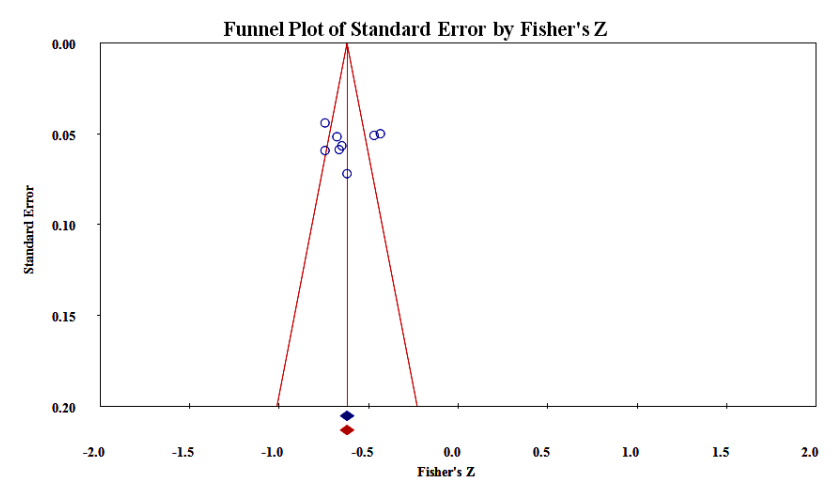

Figure 2. Funnel plot for the studies taken

When we look at the funnel it can be seen that the effect sizes of the studies gather at the upper side of the plot and there is not an extreme asymmetric situation. So it can be said that there is no publication bias; moreover, CMA software makes red typing to show us how many studies are needed. When we look at the red typing, CMA has not suggested us to any more studies. Then, once again, it can be stated that there is no publication bias. Although these are essential clues for not having publication bias, further analysis is needed to be certain. The results of Egger Test, Classic Fail Safe N and Duval \& Tweedie's Trim and Fill are given in Table 3.

Table 3. The results of egger test, classic fail safe $\mathrm{n}$ and duval \& tweedie's trim and fill

\begin{tabular}{ccccc}
\hline & & \multicolumn{2}{c}{ Duval \& Tweedie's Trim and Fill } \\
Variable & Clasic Fail Safe N & Egger Test & Trimmed & Filled \\
\hline OJ-OC & 2161 & $\mathrm{p}=.94$ & 0 & $-.55(-.55)$ \\
\hline OJ: Organizational Justice, OC: Organizational Cynicism &
\end{tabular}

OJ: Organizational Justice, OC: Organizational Cynicism

We need 2161 more studies to prevent publication bias according to Classic Fail Safe N, however; when we consider that we can only reach 8 studies in last 18 years, it seems impossible to reach such a high number. Then, this can be stated still there is not any publication bias. It was found that p-value remained insignificant which proved that there is not any publication bias. Similarly, according to Duval \& Tweedie's trim and fill model, we do not any more studies to make the funnel symmetric. All these make us certain that the effect sizes fit properly to both sides and there is no publication bias.

The overall effect sizes, for random effects models, of teachers' perception for organizational justice and cynicism degree are given in Table 4.

Table 4. The overall effect sizes, for random effects models, of teachers' perception for organizational justice and cynicism degree

\begin{tabular}{|c|c|c|c|c|c|c|c|c|}
\hline & & & & \multicolumn{2}{|c|}{$\% 95$ Confidence Interval } & \multicolumn{3}{|c|}{ Heterogeneity } \\
\hline Model & $\mathrm{k}$ & $\mathrm{N}$ & $\mathrm{ES}(r)$ & Lower limit & Upper limit & Q & $\mathrm{p}$ & $\mathrm{I} 2$ \\
\hline Random Effects Model & 8 & 2761 & -.55 & -.61 & -.49 & 46.77 & .00 & 80.96 \\
\hline Moderator Effect & $\mathrm{k}$ & & ES & Lower limit & Upper limit & $\mathrm{Qb}$ & $\mathrm{p}$ & \\
\hline Article & 5 & & -.57 & -.64 & -.50 & & & \\
\hline Dissertation & 3 & & -.52 & -.61 & -.40 & .753 & .39 & \\
\hline
\end{tabular}

The effect of teachers' perceptions for organizational justice on their experiencing organizational cynicism was calculated as $-.55[-.61 ;-.49]$ according to Table 4 . So it can be stated that teachers' perceptions for organizational justice have a strong effect on their experiencing organizational cynicism [53]. It can also be inferred that the studies' effect sizes distribute heterogeneously $(\mathrm{Q}=46.77 ; \mathrm{I} 2=80.96 ; \mathrm{p}<.05)$ by means of considering heterogeneity test, and the heterogeneity is at a high degree [60]. High degree heterogeneity points out to the existence of moderator variables which effects the calculated effect size. Publication type has been taken as a moderator through the study. However, it can be explored that publication type had no significant effect on calculated effect size $(\mathrm{Qb}=.753 ; \mathrm{p}>.05)$ which means that the effect size does not differ significantly according to publication type.

Int. J. Eval. \& Res. Educ. Vol. 8, No. 1, March 2019:189- 200 
The forest plot for the studies put in meta-analysis is shown in Figure 3. According to forest plot, the correlation coefficients for the studies investigating teachers' perception of organizational justice and degree of experiencing organizational cynicism differs from -.63 to -.41. When these 8 studies are combined under the random effects model, a negative but medium size significant relation reveals between teachers' perception for organizational justice and degree of experiencing organizational cynicism $(\mathrm{r}=-.55 ; \mathrm{p}<.05)$.

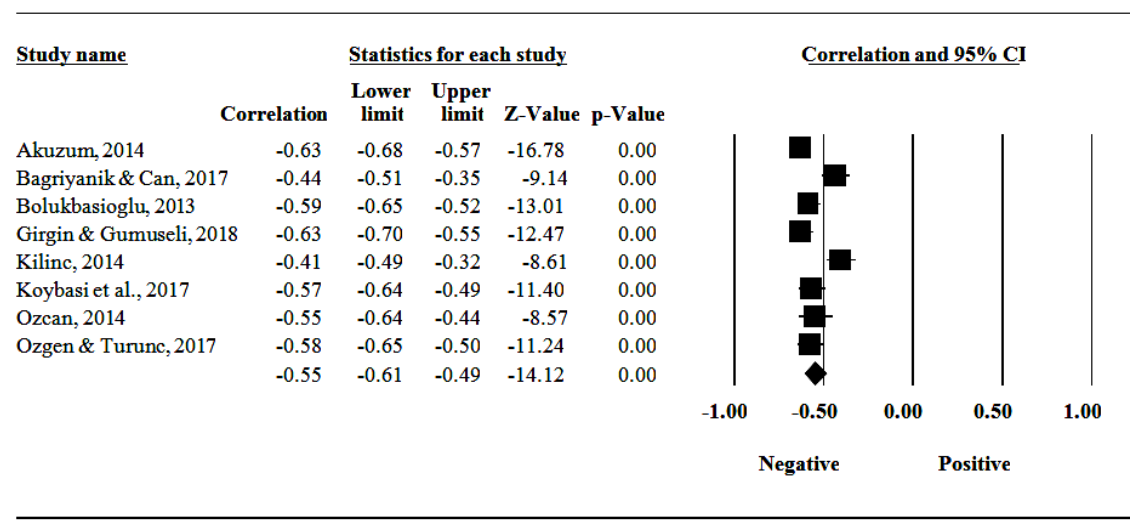

Figure 3. Forest plot

\subsection{Findings for qualitative step}

Three main themes were revealed at the end of the qualitative data analysis. These are; the reflection of unfair practices upon cognitive, emotional and behavioural dimensions of cynicism. The keywords, statements and codes related to the reflection of unfair practices upon the cognitive dimension of cynicism are given in Table 5.

Table 5. The keywords, statements and codes related to the reflection of unfair practices upon cognitive dimension of cynicism

\begin{tabular}{clc}
\hline & Keywords, Statements and Codes & $\mathrm{f}$ \\
\hline 1 & I am, now, questioning the terms like justice, rights and law & 10 \\
2 & I think that our head teachers are selfish, manipulative and acting inconsistent & 9 \\
3 & I don't think that they deserve such duties. & 9 \\
4 & I think our school will fail & 8 \\
5 & I don't think that my opinions or projects will be supported & 7 \\
6 & The rewards and promotions by school managers have lost their meaning for me & 7 \\
7 & I am teaching at an unhealthy school atmosphere. & 6 \\
8 & I feel entrapped. & 6 \\
9 & There is a culture of fear at my school. & 5 \\
10 & I believe that our school managers will find their mistakes. & 1 \\
\hline
\end{tabular}

This theme underlines what types of reactions the teachers give against unfair practices at their schools. It can be stated, according to the participants' views, that they generally have negative beliefs against the school and its managers, school managers are lack of honesty and evaluate their school climates as a closed one. As it is given in Table 5; most of the teachers are questioning the terms "justice" ( $\mathrm{f}=10$ ), managers care for their own concerns $(f=9)$, their schools will not succeed ( $f=8)$, cannot get support even if they express their ideas or projects $(\mathrm{f}=7)$. Despite the general negative expressions, only one participant stated that the school managers will find out their faults and correct them. The direct quotations for this theme are:

"My faith for justice was shaken because of unfair and discriminating practices. Thus, the promotions and rewards given by these managers do not entirely draw my interest (K5)."

"The fact that head teacher has good relations with these who agree with him while the rest are behaved unfairly has led me to gain negative opinions and increases my beliefs that with such practices school and its teachers will not succeed at all (K7)."

The participants were asked what sort of emotions they have against unfair practices at their schools. So the responses for this were analysed under the theme for the reflection of unfair practices on cynicism's emotional sub-dimension. Key-words and terms and codes are given in Table 6. 
Table 6. Key-words, terms and codes for the reflections of unfair practices on cynicism's emotional dimension

\begin{tabular}{clc}
\hline & Key-words, Terms and Codes & $\mathrm{f}$ \\
\hline 1 & Anger & 16 \\
2 & Distrust & 14 \\
3 & Sadness & 12 \\
4 & Hatred & 12 \\
5 & Unhappiness & 11 \\
6 & Lack of motivation & 11 \\
7 & Hopelessness & 10 \\
8 & Alienation & 9 \\
9 & Grudge & 8 \\
10 & Disappointment & 8 \\
11 & Anxiety & 8 \\
12 & Helplessness & 7 \\
13 & A decrease in school commitment & 7 \\
14 & A decrease in occupational esteem and reputation & 6 \\
15 & Feeling like trapped & 5 \\
16 & Feeling psychological stress & 3 \\
17 & Try to avoid negative thoughts considering my students & 1 \\
\hline
\end{tabular}

It can be stated that the participants generally have negative emotions against unfair practices and they direct these emotions to school, managers and colleagues considering Table 6 . The most frequent emotions according to teachers' views are as such anger $(\mathrm{f}=16)$, distrust $(\mathrm{f}=14)$, sadness $(\mathrm{f}=12)$, hatred $(\mathrm{f}=12)$; also the participants are observed to have emotions such as anxiety, hopelessness and helplessness. Also, the participants stated that they lost their occupational commitment and motivation against unfair practices. One of the teachers stated that considering his students, he tries to avoid such negative beliefs. Quotations for this theme are:

"Unfair practices frustrate me while this anger and jealousy makes me behave irritable and hard. My anger is not for only the head teacher but also for the teachers who support him and this unfairness (K2).",

"When I witness unfair practices, a sort of hopelessness invades me. It makes me extremely sorrow to experience such things which are totally contrary to the very nature of teaching habit. I am losing my commitment day by day (K13)."

The participants were asked what types of reactions they have against unfair practices. The responses for this were analysed under the theme of reflections of unfair practices on cynicism's behavioural dimension. The key-words, terms and codes are given in Table 7.

Table 7. The key-words, terms and codes for the reflections of unfair practices on cynicism's behavioural dimension

\begin{tabular}{clc}
\hline & The key-words, terms and codes & $\mathrm{f}$ \\
\hline 1 & I keep my school managers at a distance & 12 \\
2 & I just listen and quit during the meetings & 10 \\
3 & I do not communicate with the management unless I am to & 10 \\
4 & I, only, pay my respect to the post not to the individuals & 9 \\
5 & I do not much care for the decisions made in school meetings & 8 \\
6 & I generally rebel & 7 \\
7 & I preserve my friends to come and teach at my school & 7 \\
8 & I criticize management & 7 \\
9 & I am on my own & 5 \\
10 & I talk about these unfair practices everywhere & 5 \\
11 & I will leave this school & 3 \\
12 & I discuss with my school managers & 2 \\
13 & I will continue to do whatever is necessary for my students although I hate the & 1 \\
& managers & 1 \\
14 & I try to do my best as I love my job & 1 \\
15 & I go on to state what is right and true despite the fact that they will not be & \\
& considered & 1 \\
16 & I do not care for my teachings \\
17 & I do not share the information I have in order to make the things worse & 1 \\
18 & I organize my colleagues against management & 1 \\
\hline
\end{tabular}

Int. J. Eval. \& Res. Educ. Vol. 8, No. 1, March 2019:189- 200 
This theme focuses on what sort of reactions are made by the participants under cynicism against unfair practices. When we analyse Table 7, we can say that the participants react with an indifferent and opponent attitude against unfair practices and mostly criticise. Moreover, it can be said that some of the participants ignore these unfair practices thanks to their occupational commitment and for the sake of their students. Keeping school managers at a distance $(\mathrm{f}=12)$, staying silent during meetings $(\mathrm{f}=10)$, avoiding to communicate with management $(\mathrm{f}=10)$ are leading opinions. Also, criticism and the acts which will ruin school are also popular. Quotations for this theme are:

\begin{abstract}
"The anger changes my behaviours and makes me nervous. I usually make trouble with the responsibilities given to me and talk about these unfair practices as much as possible (K17)."

"I do not communicate with the teachers and head teacher unless I have to. I try to change the things with the ones who are close to me. But if we fail, then I either wait to change my institution or pray for the head teacher's going (K1).
\end{abstract}

\title{
4. RESULTS AND DISCUSSION
}

A detailed literature scanning was done in order to reach first-hand research studies dealing with the relationship between organizational justice and cynicism at schools in Turkey by means of the quantitative step of this study. Eight of the studies were found to be proper according to the inclusion criteria and thus taken into the analysis process. Then, it was tested whether there were any publication bias or not, and the results revealed none. Correlation coefficient and sample size were both considered in calculating effect size in terms of the random effects model.

The results of the meta-analysis on 8 research studies dealing with the relationship between teachers' organizational justice perceptions and experiencing organizational cynicism revealed that there is a negative yet strong effect of organizational justice perception on experiencing cynicism. This result is also similar to the one got by Dağyar and Kasalak [61]. Thus it can be stated that teachers who are exposed to highly unfairly practices at their schools are most likely to have organizational cynicism. The tests for moderator variables revealed that the publication type has no meaningful effect on this relationship.

Also, the results from qualitative step support these from quantitative ones like when teachers are faced with unfair conditions they are likely to develop cynics beliefs, have negative ideas and try to harm their organizations as well. Cynicism, in literature, is taken as an attitude with three separate dimensions; cognitive, emotional and behavioural. So the qualitative data were analysed in terms of these three dimensions. The first theme deals with the beliefs that the teachers have developed against unfair practices. It was found that teachers generally develop negative beliefs against the school, its managers and their colleagues in case of facing unfair practices. Teachers who think that they are teaching under unhealthy conditions believe that the school will fail, managers do not deserve these duties and their attempts will be ruined. According to Kalağan \& Güzeller [62] teachers suffering cynicism at their schools will not develops suggestions to improve their schools nor are they hope for the future of the school at all. These teachers also believe that their colleagues will not make any efforts to improve the school and thus have negative beliefs about the school. Unfair practices are accepted as a primary source of cynicism by many researchers [63, 34, 27]. So it can be stated that the results gained from the unfair practices' reflections on cynicism's cognitive dimension support the overall views in literature.

Both emotional and belief sides of perceptions support each other [42]. Consequently, teachers who have negative feelings against school and colleagues also have negative emotions against unfair practices. Anger, sorrow, hatred, alienation, loss of motivation and hopelessness are the top leading emotions against unfair practices. Unfair practices or the perception of injustice dominating people will easily surround organization with toxics [27]. To Sabuncuoğlu \& Tüz [4], cynicism includes strong emotional reactions. These emotions consist of negative feelings including anger, despising, hatred and shame against the organization. Thus it can be concluded that such negative feelings of teachers will have reflections on both themselves and the school environment.

One of the most important components of cynicism is behavioural reactions. The beliefs that the organization is lack of justice and negative emotions can be seen in teachers' behaviours. It was found that teachers generally criticize these unfair practices, stay indifferent or act against. While there are teachers trying to harm their environment as a result of this unfairness, there are also those who would ignore any such practices with thanks to their loves for the students and would do their best for the sake of students' well-being. In Fordyce's [64] phenomenological study, it was also found that cynicism occurs with criticizing, regression and participants stated that cynicism would both affect them and the school.

Organizational justice and cynicism: a mixed method study at schools (Hüseyin Akar) 
Organizational cynicism emerges as a reaction against personal experiences which result in personal or social practices with environmental effects [65]). Both qualitative and quantitative findings show that unfair practices at school are leading determinant of cynic attitude and behaviours. Attitudes, as they are under the effect of previous experiences, are likely to be changed or weakened by means of certain reforms and changes [66]. So that head teachers are expected to decrease the risk of cynicism by considering their managerial practices and taking improving precautions. Thus, they are also expected to be sensitive to individual needs and problems of teachers. The results of this study will help head teachers to recognize cynic attitudes and behaviours which thread both individuals and the school itself. Teachers' cynicism has been explored with many sides (cognitive, emotional and behavioural) according to teachers' views. Some of the participants stated that they would do their best in order to reach organizational goals thanks to their love for students and the profession. This points out the relationship between organizational commitment and cynicism. So that it can be beneficial to compare teachers' cynicism and organizational commitment.

\section{CONCLUSION}

This study is to synthesise the relationship between organizational justice perception and organizational cynicism according to current literature and to reveal what sort of cynicism occurs as a result of these unfair practices according to teachers' views. The results revealed that teachers' perceptions for organization justice have a strong but negative effect on their likelihood to experience cynicism while it was also found that publication type is not a proper moderator on effect size. On the other hand, within the qualitative analysis, it was found that teachers develop negative beliefs against school, managers and teachers; experience feelings such as anger, distrust, sadness, hatred and alienation and thus criticize school and managers, behave recklessly and opponent as a result of unfair practices.

\section{REFERENCES}

[1] C. Unterhitzenberger, \& D. J. Bryde, "Organizational justice, project performance, and the mediating effects of key success factors," Project Management Journal, vol. 50, pp. 1-14, 2018.

[2] J. A. Colquitt, \& J. Greenberg, "Organizational justice: A fair assessment of the state of the literature," In J. Greenberg (Ed.), Organizational behavior: The state of the science, pp.165-201. Mahwah, NJ: Erlbaum, 2003.

[3] G. Budak, E. Tolay, O.B. Sezgin, S. Ç. Arpac1, \& S. G. Aksu "Örgütsel adalet," Nobel Akademi Yayınclık, Ankara, 2018.

[4] Z. Sabuncuoğlu, \& M. V. Tüz, "Örgütsel davranış," Aktüel Yayınlari, Bursa 2013.

[5] E. Ünler, \& H. Gürel, "Örgütsel adalet peşinde," Beta Yayınları, İstanbul, 2015.

[6] R. Cropanzano, D. E. Bowen, \& S. W. Gilliland, "The management of organizational justice," Academy of Management Perspectives, vol. 21 pp. 34-48, 2007.

[7] T. A. Judge, \& J. A. Colquitt, "Organizational justice and stress: the mediating role of work-family conflict," Journal of Applied Psychology, vol. 89, pp. 395-404, 2004.

[8] E. Özkalp, \& Ç. Kırel, "Örgütsel davranış," Ekin Basın Yayın Dağıtım, Bursa, 2016.

[9] J. Greenberg, "Organizational justice: Yesterday, today, and tomorrow," Journal of Management, vol. 16, pp. 399-432, 1990.

[10] J. Greenberg, "A taxonomy of organizational justice theories," Academy of Management Review, vol. 12, pp. 9-22, 1987.

[11] M. A. Konovsky, "Understanding procedural justice and its impact on business organizations," Journal of Management, vol. 26, pp. 489-511, 2000.

[12] R. J. Bies, \& J. S. Moag, "Interactional communication criteria of fairness." Research in organizational behavior, vol. 9, pp. 289-319, 1989.

[13] P. Blau, "Power and exchange in social life," J Wiley \& Sons, New York, 1964.

[14] R. Cropanzano, C. A. Prehar, \& P. Y. Chen, "Using social exchange theory to distinguish procedural from interactional justice," Group \& Organization Management, vol. 27, pp. 324-351, 2002.

[15] M. Erdoğdu, "Effect of organizational justice behaviors on organizational silence and cynicism: a research on academics from schools of physical education and sports," Universal Journal of Educational Research, vol. 6, pp.733-741, 2018 .

[16] P. Addaia, E. Kyeremeh, W. Abdulai, \& J.O. Sarfo, "Organizational justice and job satisfaction as predictors of turnover intentions among teachers in the Offinso South District of Ghana," European Journal of Contemporary Education, vol. 7, pp. 235-243, 2018.

[17] B. Buluc, \& M. Gunes, "Relationship between organizational justice and organizational commitment in primary schools," The Anthropologist, vol. 18, pp. 145-152, 2014.

[18] Y. Akman, "The investigation of the relationships between organisational justice, work motivation and teacher performance," Cukurova University Faculty of Education Journal, vol. 47, pp. 164-187, 2018.

Int. J. Eval. \& Res. Educ. Vol. 8, No. 1, March 2019:189- 200 
[19] R. Ertürk, \& B. Aydın, "İlkokul ve ortaokul öğretmenlerinin örgütsel adalet ve içsel motivasyona yönelik algılarının incelenmesi," Uluslararası Eğitim Bilimleri Dergisi/The Journal of International Education Science, vol. 2, pp. 233-246, 2015.

[20] S. Yürür, \& C. Mengenci, "Örgütsel adalet ve ekstra-rol davranışlart ilişkisi," Yönetim ve Ekonomi Araştırmaları Dergisi, vol. 12, pp. 1-17, 2014.

[21] A. Köse, \& M. Uzun, "The relationship between work engagement and perceived organizational justice," Kuram ve Uygulamada Ĕ̈itim Yönetimi, vol. 24, pp. 483-528, 2018.

[22] S. Yürür, "Örgütsel adalet, A. Keser, G. Yılmaz, S. Yürür içinde, "Çalışma yaşamında davranış: Güncel yaklaşımlar, Umuttupe Yayınları, pp. 197-208, İstanbul, 2009.

[23] M. R. FitzGerald, "Organizational cynicism: Its relationship to perceived organizational injustice and explanatory style," (Unpublished Doctoral Disseration). University of Cincinnati, Cincinnati, 2002.

[24] K. Demir, "Örgütsel sinizm, S. Özdemir, N. Cemaloğlu içinde," Örgütsel davranış ve yönetimi. Pegem Akademi Yayıncılık, pp. 577-594, Ankara, 2017.

[25] J. S. C. Yim, \& P. Moses, "Work factors and teacher satisfaction: The mediating effect of cynicism toward educational change," Issues in Educational Research, vol. 26, pp. 694-709, 2016.

[26] L. Navia, "Classical cynicism: A critical study," Greenwood Press, London, 1996.

[27] M. E. Kart, "Örgütsel sinizm bağlamsal peroformans ve etik ideoloji," Nobel Akademik Yayıncılık, Ankara, 2015.

[28] P. Brandes, \& D. Das, "Locating behavioral cynicism at work: Construct issues and performance implications. In Employee health, coping and methodologies," Emerald Group Publishing Limited, 2006.

[29] J. Bond, \& R. Kirshenbaum, "Under the radar: Talking to today's cynical consumer," Wiley, New York ,1998.

[30] R. Ö. Kutanis, \& A. Dikili, "Değişim boyutunda örgütlerde sinizm, D.E. Özler (Ed.) içinde", Örgütsel davranışta güncel konular, pp. 269-285, Bursa: Ekin Basım Yayın Dağıtım, 2010.

[31] J. W. Dean, P. Brandes, \& R. Dharwadkar, "Organizational cynicism," Academy of Management Review, vol 23, pp. 341-352, 1998.

[32] T. E. Miller, "Effects of transformational leadership on employee's organizational cyncism in an educational organization," (Unpublished Doctoral Disseration). California State University, California, 2018.

[33] M. Aydın, "Eğitim yönetimi," Gazi Kitabevi, Ankara, 2014.

[34] F. Naus, A. Van Iterson, \& R. Roe, "Organizational cynicism: Extending the exit, voice, loyalty, and neglect model of employees' responses to adverse conditions in the workplace," Human Relations, vol. 60, pp. 683-718, 2007.

[35] J. A. Eaton, "A social motivation approach to organizational cynicism," (Unpublished Doctoral Dissertation), Graduate Program in Psychology. York University, Toronto, 2000.

[36] G. Kasalak, \& B. Güneri, "Ortaöğretim kurumlarında örgütsel sinizm ve örgüt adaletin örgütsel bağlllık üzerindeki etkisi," Uluslararası Ĕgitim Bilimleri Dergisi, vol. 11, pp. 416-434, 2017.

[37] J. Baig, N. K. Soon, A. A. Elmabrok, S. Shanker, N. M. X. Sirisa, \& A. R. Ahmad, "Causes of organizational cynicism and its consequence on teaching staff in Malaysia," Indian Journal of Science and Technology, vol. 9, 2016.

[38] O. Yaşar, \& A. Özdemir, "The relationship of organizational cynicism, burnout, and organizational commitment: A study on middle school teachers." Eurasian Academy of Sciences Eurasian Business \& Economics Journal, vol. 6, pp. 50-61, 2016.

[39] K. Yıldız, N. Akgün, \& S. Yıldız, "İşe yabancılaşma ile örgütsel sinizm arasındaki ilişki," The Journal of Academic Social Science Studies, vol. 6, pp. 1253-1284, 2013.

[40] C. Aküzüm, "The effect of organizational justice and organizational Cynicism on the organizational commitment: An application in primary education institutions," Mevlana International Journal of Education (MIJE), vol. 4, pp. 48-68, 2014.

[41] H. Bağrıyanık, \& N. Can, "The Relation between teachers' perception of ethical leadership, organizational justice and organizational cynicism," Journal of Studies in Education, vol. 7(2), 1-16, 2017.

[42] K. Bölükbaşığlu, "Öğretmenlerin örgütsel adalet algıları ile örgütsel sinizm tutumları arasındaki ilişki." (Unpublished Master's Thesis ). Pamukkale Üniversitesi, Denizli, 2013.

[43] S. Girgin, \& A. İ. Gümüşeli, "A study on the correlation between organizational justice and organizational cynicism perceived by vocational high school teachers," European Journal of Education Studies, vol. 4, pp. 445-457, 2018.

[44] S. Kılınç, "Örgütsel adaletin, örgütsel vatandaşlık davranışı ve örgütsel sinizm tutumlarına etkisi: Malatya ili öğretmenleri üzerine bir uygulama," (Unpublished Master's Thesis). Türk Hava Kurumu Üniversitesi, Sosyal Bilimleri Enstitüsü, Ankara, 2014.

[45] F. Köybaşı, C. T. Uğurlu, \& A. Öncel, "Öğretmenlerin örgütsel adalet algıları ile örgütsel sinizm düzeyleri arasındaki ilişkinin incelenmesi," İø̈nü Üniversitesi Eğitim Fakültesi Dergisi, vol. 18, pp. 1-14, 2017.

[46] F. Ö. Özgen, \& Ö. Turunç, "Örgütsel adalet-sinizm ilişkisinde kişi örgüt uyumunun rolü: eğitim sektöründe bir araştırma," Uluslararası Íktisadi ve İdari Bilimler Dergisi, vol. 3, pp. 80-96, 2017.

[47] E. Özcan, "Öğretmenlerin örgütsel adalet algıları ile örgütsel sinizm tutumları arasındaki ilişki," (Unpublished Master's Thesis). Kocaeli Üniversitesi, Sosyal Bilimler Enstitüsü, Kocaeli, 2014.

[48] C. Teddlie, \& A. Tashakkori, "Foundations of mixed methods research. Integrating quantitative and qualitative approaches in the social and behavioral sciences," Sage, Thousand Oaks, CA, 2019.

[49] A. Yıldırım, \& H. Şimşek, "Nitel araştırma yöntemleri," Seçkin Yayınevi, Ankara, 2008.

[50] L. B. Chiristensen, R. B. Johnson, \& L. A. Turner, "Araştırma yöntemleri: Desen ve analiz," (Aypay, A. Çev. Ed.), Anı Yayıncılık, Ankara, 2015.

[51] T. Baş, \& U. Akturan, "Sosyal bilimlerde bilgisayar destekli nitel araştırma yöntemleri." Seçkin Yayıncıllk, Ankara, 2017. 
[52] M. Borenstein, L. V. Hedges, J.P.T. Higgins, \& H.R. Rothstein, "İntroduction to meta-analysis," Hoboken, N.J.: Wiley, 2017. Retrieved from http://rbdigital. oneclickdigital.com.

[53] L. Cohen, L. Manion, \& K. Morrison, "Research methods in education," Routledge, 2013.

[54] S. B. Merriam, "Nitel araştırma: Desen ve uygulama için bir rehber," (S. Turan, Çev. Ed.), Nobel Akademik Yayıncılık, Ankara, 2013.

[55] W. L. Neuman, "Toplumsal araştırma yöntemleri," (S. Özge Çev.), Yayınodası Yayınları, İstanbul, 2012.

[56] J. W. Creswell, "Nitel araştırma yöntemleri: Beş yaklaşıma göre nitel araştırma ve araştırma deseni," (M. Bütün; S. B. Demir, Çev. Ed.), Siyasal Kitabevi, Ankara, 2013.

[57] M.Q. Patton, "Nitel araştırma ve değerlendirme yöntemleri," (M. Bütün; S.B. Demir, Çev. Eds.), Pegem Akademi, Ankara, 2014.

[58] B. M. Miles, \& A. M. Huberman, "Qualitative data analysis," SagePub, London, 1994.

[59] A. P. Field, \& R. Gillett, "How to do a meta-analysis. British Journal of Mathematical and Statistical Psychology, vol. 63, pp. 665-694, 2010.

[60] J. P. Higgins, S. G. Thompson, J. J. Deeks, \& D. G. Altman, "Measuring inconsistency in meta-analyses," BMJ: British Medical Journal, vol. 327, 2003.

[61] M. Dağyar, \& G. Kasalak, "Eğitim örgütlerinde yaşanan örgütsel sinizmin öncülleri ve sonuçları üzerine bir metaanaliz çalışması," Hacettepe Üniversitesi Ĕ̌itim Fakültesi Dergisi, vol. 33, pp. 967-986, 2018.

[62] G. Kalağan, \& C. O. Güzeller, "Öğretmenlerin örgütsel sinizm düzeylerinin incelenmesi," Pamukkale Üniversitesi Eğitim Fakültesi Dergisi, vol. 27, pp. 83-97, 2010.

[63] D. J. Goodman, "Promoting diversity and social justice: Educating people from privileged groups," Routledge, 2011.

[64] V. H. Fordyce, "Cynicism in Christian secondary schools: A phenomenology," (Unpublished Doctoral Disseration), University of Nebraska, Omaha, 2007.

[65] M. S. L. James, "Antecedents and consequences of cynicism in organizations: An examination of the potential positive and negative effects on school systems," (Unpublished Doctoral Disseration). The Florida State University, Florida, 2005.

[66] E.Eren, "Örgütsel davranış ve yönetim psikolojisi," Beta Basım Yayım Dağıtım, İstanbul, 2014.

\section{BIOGRAPHIES OF AUTHORS}

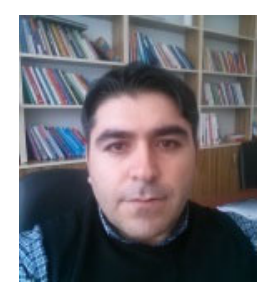

Dr. Hüseyin AKAR is an Assistant Professor attached to the Muallim Rifat Faculty of Education at Kilis 7 Aralı University in the Department of Educational Administration. His research and publication interests include topics such as quality of work life, social entrepreneurship, organizational behavior, and leadership. He has presented papers at national and international congresses and published articles in various journals.

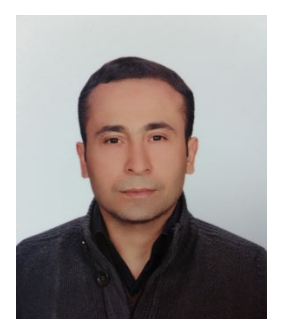

Dr. Osman Tayyar ÇELIKK completed his PhD at Inonu University Educational Administration and Supervision Program. He has been working as a lecturer at Pamukkale University Student's Affairs Office. His research interests are teacher training, teacher empowerment, leadership and school improvement. 